\title{
Molecular enhancement of sentinel node evaluation
}

\author{
Alistair J. Cochran \\ From Melanoma Bridge Meeting 2014 \\ Naples, Italy. 03-06 December 2014
}

Lymphatic mapping and sentinel node biopsy are widely used to stage and manage patients with intermediate and thicker primary cutaneous melanoma. Likelihood of sentinel node metastases can be estimated from patients' demography and primary tumor characteristics, but is precisely determined only by microscopic evaluation of excised node(s). Molecular/Genetic techniques, such as RT-PCR, Gene Expression Microarray, detection of metastasis-associated gene signatures and gene sequencing are likely to increase precision in future. Recent 10 year results of Multicenter Selective Lymphadenectomy Trial 1 (MSLT1) [1] confirm that biopsy-based management prolongs disease free survival for all nodepositive patients $(\mathrm{P}=0.01-0.03)$ and significantly increases 10 year distant disease-free survival $(\mathrm{P}=0.006)$ and melanoma-specific survival $(\mathrm{P}=0.02)$ for node-positive patients with intermediate thickness primaries. The trial also confirmed very clearly that the presence or absence of sentinel node metastases is best determined by close pathological evaluation of sections from nodal tissues, stained conventionally and by immunohistochemistry (S-100 protein, Mart-1, HMB-45). Patients with sentinel node metastases have a significantly unfavorable outcome that correlates with the amount and disposition of nodal tumor as assessed by microscopy, immunohistochemistry and morphometry [2]. Here again precision will be increased by the parallel application of molecular and genetic tests. The accuracy of appropriate patient assignment to early surgical management will be dramatically increased by the addition of molecular testing, more precisely identifying the patients most likely to respond to standard and evolving therapies
Acknowledgment

Studies supported by the US National Institutes of Health: CA 29605.

Published: 15 January 2015

\section{References}

1. Morton DL, Thompson JF, Cochran AJ, Mozzillo N, Nieweg OE, Roses DF, Hoekstra HJ, Karakousis CP, Puleo CA, Coventry BJ, Kashani-Sabet M, Smithers BM, Paul E, Kraybill WG, McKinnon JG, Wang HJ, Elashoff R, Faries MB, MSLT Group: Final trial report of sentinel-node biopsy versus nodal observation in melanoma. N Engl J Med 2014, 370(7):599-609.

2. Cochran AJ, Wen DR, Huang RR, Wang HJ, Elashoff R, Morton DL: Prediction of metastatic melanoma in nonsentinel nodes and clinical outcome based on the primary melanoma and the sentinel node. Mod Pathol 2004, 17(7):747-755.

\section{doi:10.1186/1479-5876-13-S1-K4}

Cite this article as: Cochran: Molecular enhancement of sentinel node evaluation. Journal of Translational Medicine 2015 13(Suppl 1):K4.

Submit your next manuscript to BioMed Central and take full advantage of:

- Convenient online submission

- Thorough peer review

- No space constraints or color figure charges

- Immediate publication on acceptance

- Inclusion in PubMed, CAS, Scopus and Google Scholar

- Research which is freely available for redistribution 